\title{
Fish physiology and ecology: the contribution of the Leigh Laboratory to the collision of paradigms.
}

\author{
N W Pankhurst ${ }^{\mathrm{a}}$ and N A Herbert ${ }^{\mathrm{b}}$ \\ a Australian Rivers Institute, Griffith University, Gold Coast, Qld 4222 Australia; ${ }^{\text {b Leigh }}$ \\ Marine Laboratory, Institute of Marine Science, The University of Auckland, Warkworth \\ 0941, New Zealand
}

The often pragmatic division of studies of function (physiology), and the regulation of distribution and abundance of organisms (ecology), as laboratory and field studies respectively, can create an unhelpful intellectual division that runs the risk of ignoring the interaction of physiology, behaviour and environment that regulates the lives of animals in the wild. This review examines the historical and current contribution of ecophysiological research conducted from the University of Auckland's Leigh Laboratory in bridging these paradigms, and generating new insights into animal function and community organisation. The assessment focusses on endocrine control processes, and metabolic and behavioural responses of fish to artificial and natural stressors, and examines tracks of future research needed to underpin understanding of likely effects of predicted environmental change on individuals and populations.

Keywords: Ecophysiology, teleost fish, stress, reproduction, metabolism, climate change, hypoxia 


\section{Introduction}

The study of the integrated hierarchy of molecular, cellular, tissue, individual, population and system-level processes in biology has often been further complicated in not always helpful ways, by the relatively arbitrary definition of discipline or study boundaries at various levels of organisation. Classically this has been most strongly typified by the separation of function (investigation of plant and animal physiology) from the biological setting in which this function has to occur (the broad field of ecology). Definitions of physiology and ecology in turn vary, but those provided by Withers (1992) and Krebs (1994) illustrate the point. Physiology can be defined as "the study of the biological processes that enable [organisms] to exist and function" (Withers 1992) and Krebs (1994) presents ecology as "the scientific study of the interactions that determine the distribution and abundance of organisms". The difficulty is that both broad disciplines require assessment and understanding of the other to properly contextualise the integrated processes that connect the hierarchy described above. This concern was behind the genesis of a stream of biological research that developed most rapidly in the last decades of the twentieth century and attempted to bring the two ways of thinking about biological processes together through a new discipline of ecophysiology. Rankin \& Jenson (1993) define ecophysiology as "how the physiology of [organisms] is affected by and regulated in response to environmental changes... the limits of environmental factors within which animals can function and populations be sustained" (Rankin \& Jensen 1993). An important aspect of ecophysiology is that it also allows assessment of behaviour as part of an animal's repertoire in responding to that change.

The ecology-physiology dichotomy is in many respects delineated by pragmatism as much as philosophy. The study of animal function typically involves experiment under controlled conditions, whereas ecology is by definition fundamentally a field science. The study of animal function in the natural environment requires a base level of understanding 
derived from laboratory studies, the capacity to manipulate or measure aspects of animal function in the wild, and some comfort that the measurement processes themselves do not distort the outcomes. These requirements generate a subset of limiting conditions that mean ecophysiological investigations need a number of conditions precedent to be practical and relevant. This review discusses the role of the University of Auckland's Leigh Laboratory in contributing to the development of this approach for fish in the near-shore marine context, and also examines some of the impacts that this has had on the field more broadly, and the opportunities that these present for research against a global framework of environmental change and challenge.

The Leigh Laboratory offered a unique opportunity for examining animal function through the lens of ecophysiology and this opportunity had several facets. The first was the decision by the University of Auckland in 1962 to establish a field station at Goat Island and over time, to develop this into a substantial and well-equipped marine research facility. The second was the development of SCUBA-based underwater research and a long term underwater habitat mapping and assessment program (Ayling et al. 1981) on establishment in 1975 of the adjacent Cape Rodney to Okakari Point (Leigh) Marine Reserve - the first of New Zealand's network of no-take marine preservation areas. One effect of this preservation was the reappearance of a range of large demersal fish species and with this, the development of diver-neutral and in some cases, diver-positive fish behaviour (Cole et al. 1994; Babcock et al. 1999). A final ingredient was provided through the presence of champions of physiology motivated by the question of how closely the laboratory paradigms of physiology actually represented the way that animals functioned in the wild (e.g. Ling \& Wells 1985a,b; Wells 1987, 2009). Some of these questions evolved into related parallel tracks of investigation of fish metabolism, and the control processes managed through the fish endocrine system and these are considered further here. 


\section{Environmental responses modulated by the endocrine system}

\section{Stress}

There is now extensive literature on the physiological and endocrine basis of stress in fish, largely constructed from studies of captive or cultured fish, and within this, largely examining the effects on teleost fishes (see reviews by Wells 1987; Barton and Iwama 1991; Pickering 1998; Sumpter 1997; Wendelaar Bonga 1997; Barton 2002). The stress response in teleosts is biphasic with an initial short latency increase in plasma levels of catecholamines released from stores in the chromaffin tissue of the kidney, followed by a longer latency but usually more prolonged elevation in plasma cortisol levels following de novo synthesis by interrenal tissue (reviewed in Pankhurst 2011). Rapid increases in plasma levels of the catecholamines, adrenaline and noradrenaline occur in response to severe acute stress, especially if this involves significant reductions in blood oxygen content. Effects of increased plasma levels of catecholamines include increased haemoglobin oxygen affinity, increased arterial blood pressure and release of stored hepatic glycogen to the plasma as glucose (Pankhurst 2011). Activation of the corticosteroid stress response occurs via the stimulation of the hypothalamo-pituitary-interrenal (HPI) axis, through serial activation of corticotropin releasing factor (CRF) from the hypothalamus in the brain, adrenocorticoptrophic hormone (ACTH) by the pituitary gland, and steroidogenesis in the interrenal tissue, resulting in the release of cortisol to the circulation (Pankhurst 2011). The timecourse for the appearance of elevated cortisol levels in the plasma following stress varies among species but typically has a latency of about 10 minutes, and this response is relatively independent of temperature (Pankhurst 2011). This means that provided fish are at a resting or basal level at the time of sampling, there is a window in which capture and sampling (itself a stressful procedure) can occur with reasonable certainty that the sampling procedure is not affecting the measurement variables. 
Because there was initially very limited data on stress responses from fish in the wild, it was not known how closely the laboratory or aquaculture facility-based experiments represented the situation in the wild. The capacity to approach naturally behaving fish in the Leigh Marine Reserve on SCUBA offered the opportunity to test this. Early experiments showed that it was possible for divers to hand-net fish (in this case New Zealand snapper Pagrus auratus) off the reef, and within 30-60 seconds of capture, extract a blood sample underwater (Pankhurst \& Sharples 1992)(Fig. 1). An interesting outcome of this work was that while snapper in captivity showed a rapid increase in plasma cortisol levels following capture, confinement and blood-sampling similar to that displayed by other species, (Pankhurst et al. 1992; Lowe and Wells 1996), the same treatment in the field using a small, weighted keep-net took as long as 30 minutes to elicit an increase in plasma cortisol, i.e. the stress response was highly context-specific. A similar effect of context has been described in ecophysiological studies of stress in free-living birds (Cockrem In press). Underwater sampling of an additional 7 species from Leigh using SCUBA, 4 species sampled underwater from a large public aquarium, and 6 rapidly-angled species showed that baseline levels of plasma cortisol were typically less than $10 \mathrm{ng} \mathrm{ml}^{-1}$, and very often below $2 \mathrm{ng} \mathrm{ml}^{-1}$ (Pankhurst 2011). This confirmed the suspicion that the often much higher basal levels reported from studies on captive stock (Pankhurst et al. 1992; Lowe and Wells 1996) were most likely artefacts of husbandry or experimental conditions. Notable exceptions (eg. migrating salmonids, Pankhurst \& Dedual 1994; some warm water species, Magee et al. 2006) were then able to be validated against sampling strategies known not to produce capture artefacts. An additional observation was that captive fish recovered and returned to baselines of plasma cortisol but these levels were always higher than those of fish in the wild; i.e. recovery under laboratory conditions was incomplete, even after extended periods of holding (Pankhurst et 
al. 1992) suggesting that many laboratory investigations of stress may actually begin with fish that are in a chronically stressed state.

The fact that plasma cortisol levels in a large number of individuals of a range of species across different seasons and reproductive states are typically low, does raise the question of whether fish in the natural environment actually experience stress in the way it has been characterised from studies of captive fish. As discussed in Pankhurst (2011), the capture and confinement regimes typically used to elicit stress in laboratory situations might only equate in the wild to extreme events such as pursuit and capture by a predator, where the outcomes are more proximate and as a result, stress responses of the type seen in the laboratory may in consequence, be quite rare. This question still remains to be examined but it is a perspective that would have been unlikely without the underwater-based studies conducted through the Leigh Laboratory.

\section{Reproduction}

\section{Stress and reproduction}

Imposition of both acute and chronic stress had been shown to have a largely inhibitory effect on growth and reproduction, based on evidence largely drawn from captive or domesticated stocks (reviewed in Pankhurst \& Van Der Kraak 1997). What was less clear was the relationship between stress and reproduction in wild stocks of fish. The capacity through the Leigh Laboratory and the associated marine reserve to assess endocrine correlates of stress and reproduction in wild fish both before and after exposure to stress provided the opportunity to address this question.

The fish reproductive endocrine pathway or cascade mirrors that of the stress pathway, with changes in environmental variables being transduced into effects on reproductive processes through the hypothalamo-pituitary-gonadal (HPG) axis, with hypothalamic 
synthesis and synaptic release of peptide gonadotropin releasing hormones $(\mathrm{GnRH})$ to the pituitary gland stimulating the synthesis and release of follicle stimulating hormone (FSH) and luteinising hormone (LH). FSH is involved in stimulating the early stages of gamete development, and LH in the control of maturational events, with both exercising their effects at the gonadal level through de novo synthesis and release of gonadal steroids. Male fishes typically produce the androgens, testosterone (T) and 11-ketotestosterone (11KT), and females also produce $\mathrm{T}$ which is then metabolised to the estrogen $17 \beta$-estradiol $\left(\mathrm{E}_{2}\right)$. Both sexes also produce a progesterone-like maturational steroid (17,20 $\beta$-dihydroxy-4-pregnen-3one $[17,20 \beta \mathrm{P}]$ or $17,20 \beta, 21$-trihydroxy-4-pregnen-3-one [20ß-S]) in response to gonadal stimulation by LH (reviewed in Pankhurst \& Munday 2011). Early studies had shown that T, $11 \mathrm{KT}$ and $\mathrm{E}_{2}$ were all inhibited by stress with consequent suppression of a range of reproductive functions (reviewed in Schreck 2010).

Investigation of stress effects on New Zealand snapper and red gurnard (Chelidonichthys kuтu) showed that the inhibitory effect of stress was rapid and profound with falls of $\mathrm{T}$ and $\mathrm{E}_{2}$ to undetectable levels within a day of capture (Carragher \& Pankhurst 1991; Clearwater \& Pankhurst 1997). Falls in plasma steroid levels were followed soon after in females by the development of follicular atresia and the loss of vitellogenic follicles from the ovary (vitellogenic or yolk-forming follicles represent the oocyte stock that will mature and be spawned in the current reproductive event or season). The primary basis for this effect lies in the role of $E_{2}$ in stimulating the hepatic synthesis of the yolk precursor vitellogenin for uptake into the growing oocytes (Pankhurst \& Munday 2011). Subsequent laboratory maintenance of snapper and other species showed that while there is recovery from stress under suitable holding conditions, there is generally no subsequent recovery of reproductive function (Pankhurst 1998). The practical implication of this is that wild stocks seldom acclimate to captivity in reproductive terms, and hormonally-induced maturation of wild broodstock 
works best when fish are treated with exogenous hormones immediately after capture, before the inhibitory effects of stress are expressed (Haddy \& Pankhurst 2000; Cleary et al. 2002). Subsequent cultured generations also show stress suppression of reproduction but greater capacity to recover following the resolution of stress (Pankhurst 1998), consistent with evidence that stress responses are heritable and that culture probably selects for stressresistant individuals (reviewed in Pankhurst 2011). A developing understanding of stressreproduction dynamics in fish defined sampling approaches that in turn gave confidence to subsequent field studies of reproductive endocrine correlates in a range of species (Dedual \& Pankhurst 1992; Carragher \& Pankhurst 1993; Clearwater \& Pankhurst 1994; Hobby \& Pankhurst 1997; Poortenaar et al. 2001, 2004).

\section{Reproductive behaviour}

Examination of a range of aquarium or cultured fish species had demonstrated a strong relationship between reproductive behaviour and plasma levels of reproductive hormones, and as in terrestrial vertebrates much of this attention had been directed at the role of androgens in mediating territorial and aggressive behaviours (Stacey 1984). There was at this time, considerably less information available on hormone-behaviour interactions in freeliving populations and this tended to be restricted to spawning migrations or events where fish could be captured and sampled from the shore (eg. Scott et al. 1984; Stacey et al. 1984). There was very little known about these relationships in marine species. The capacity to capture and sample fish underwater developed through the Leigh Laboratory allowed the real-time correlation of plasma hormone levels with coincident behaviours.

A series of investigations of the northern New Zealand pomacentrid Chromis dispilus showed the expected relationship between spawning and nesting behaviour of territorial males and plasma levels of $\mathrm{T}$ and $11 \mathrm{KT}$ but also of the maturational steroid 17,20 $\beta \mathrm{P}$ 
(Pankhurst 1990). Previously this hormone had been thought to be primarily associated with stimulation of spermiation in males. Examination of both territory-holding, and non-territorial males showed that all males showed cyclic changes in plasma androgens, albeit at higher levels during spawning among territory-holders, but only territory-holders ever showed elevated $17,20 \beta \mathrm{P}$ levels; i.e. this hormone was strongly implicated in the mediation of spawning behaviour (Barnett \& Pankhurst 1994). Elevations in gonadal steroids during spawning were also accompanied by elevated plasma LH levels, suggesting that behavioural alterations of reproductive endocrine status are mediated through the action of GnRH (Pankhurst \& Peter 2002).

Sampling of populations across an increasing density gradient from the Leigh laboratory to outer islands of the adjacent Hauraki Gulf demonstrated another aspect to this relationship. At higher densities, nest sites became more closely spaced and this resulted in a higher frequency of both spawning events and territorial encounters among males in these territories. This was accompanied by density-driven elevations in plasma levels of $17,20 \beta \mathrm{P}$ and to a lesser extent 11KT (Pankhurst \& Barnett 1993; Barnett \& Pankhurst 1996). These studies combined with underwater manipulation of plasma hormone levels and nest status (Pankhurst \& Carragher 1995) allowed the modelling of hormone-behaviour interactions in male $C$. dispilus, and demonstrated that hormone levels could both modulate and be modulated by reproductive behaviour under various conditions (Pankhurst 1995) (Fig. 2). These relationships have been confirmed across a range of species and settings using similar approaches to those pioneered here, in other studies at Leigh (Pankhurst\& Kime 1991) and elsewhere (eg. Kindler et al. 1989; Cardwell \& Liley 1991; Sikkel 1993; Pankhurst et al. 1999, 2008a,b; Magee et al. 2006).

Underwater sampling and, or hormone manipulation with associated scope for behavioural observation has been particularly effective in the tropical setting at locations 
where the "Leigh Laboratory" conditions also apply through the juxtaposition of laboratory and diving support facilities, and close access to the natural environment. Some examples include the demonstration of hormone-behaviour interactions among territorial males of tropical pomacentrids (Pankhurst et al. 1999) and the role of population density in determining reproductive performance (Pankhurst et al. 2008a,b); the effect of maternal cortisol profiles on larval and juvenile performance, and stress and maternal effects in pomacentrids (McCormick 1998, 2006; Pankhurst 2001), endocrine correlates of bidirectional sex change in gobies (Kroon et al. 2003, 2009) and the effects of ectoparasite load on stress status of wrasses (Grutter \& Pankhurst 2000).

\section{The metabolic response of fish to handling and capture stress}

Energy is the fundamental currency of life, so the impact of stress on the subsequent day-today activity of fish (or even flesh quality of angled fish) is influenced strongly by the manner in which useable energy (adenosine triphosphate - ATP) is created and consumed through aerobic and anaerobic metabolic pathways (Wells 1987, Lowe et al. 1993). The coastal waters around Leigh are host to a wealth of sport fishes so the early efforts of physiologists at the Leigh Laboratory were dedicated to understanding the metabolic effect of stress from line capture and associated handling (Ling and Wells 1985a,b; Wells 1987). These findings were at the forefront of stress physiology research in the 1980s and continued with the integration of endocrinology in the early 1990s (e.g. Ling and Wells 1985b; Bollard et al. 1993, Lowe and Wells 1996). This research confirmed that, as in the laboratory, the primary stress response of fish to angling /handling involved sequential increases of catecholamines and then corticosteroids,(Lowe et al. 1993; Lowe and Wells 1996) serving to modulate the metabolite status, the blood oxygen carrying capacity, blood viscosity and even cell maintenance function of fish to satisfy and protect against the sudden increase in energy 
demand (Ling and Wells 1985b; Pankhurst et al. 1992; Lowe et al. 1993; Ryan et al. 1995; Lowe and Wells 1996). Of particular interest are the manipulative experiments of Bollard et al. (1993) that artificially raised plasma cortisol levels in snapper and showed for the first time that cortisol in fish retains lactate in circulation which, through follow-up research, is now believed to be a mechanism providing metabolic fuel post-exercise (Eros and Milligan 1996). Stress research at Leigh subsequently developed into a more applied arena of work showing that physiological stress (acidified tissues and depleted energy reserves) has a marked negative impact on the flesh quality of snapper (Wells 1987; Lowe et al. 1993) but, interestingly, novel "hypnotic" techniques could alleviate stress if applied correctly (Wells et al. 2005).

\section{Metabolic physiology and the adaptive radiation of New Zealand fishes}

True to a core goal of eco-physiology of resolving physiological features that de-limit the ecological and biogeographical distributions of fish, a number of notable studies have benefited from the Leigh Laboratory and its field facilities. For example, the oxygen binding properties inherent of the multiple haemoglobins found among different triplefin species and herbivorous marine teleosts from the Leigh area provide examples that associate phenotype with environment. The functional properties of fish haemoglobin isoforms appear to match species physiological requirements to function in thermally stable (deep) or unstable (shallow) habitats (Brix et al. 1998, 1999). The triplefin assemblage provides a particularly useful model because the triplefin phylogeny has largely been resolved, and this permits the attribution of phenotypic differences among species to that of adaptation, or simple phylogeny (Hickey and Clements 2005). The PhD theses of Hickey (2004) and Hilton (2010) from the University of Auckland's School of Biological Science used this endemic fish 
assemblage to test whether the triplefin radiation is an adaptive radiation, where each species has harnessed particular physiological traits to secure its niche. Evidence of trait utility with respect to the structure of swimming musculature and metabolic enzyme activity (Hickey and Clements 2003) as well as temperature and low $\mathrm{O}_{2}$ tolerances in mitochondrial function and whole animal metabolism (Hilton et al. 2008, 2010) has indeed been suggested by these studies. All these studies provide accumulating evidence that physiological adaptation has played a role in the radiation of this fascinating group of fishes.

\section{The metabolic and behavioural response of fish to environmental stressors}

In addition to how energy is made available to fish during handling stress, environmental extremes have a strong influence over ATP production and thus governs where fish can and cannot live (Cucco et al. 2012; Teal et al. 2012). For example, the energy demand of ectotherms increases with temperature so excessive elevation from "global warming" threatens to extend the ATP production rate of fishes to its limit (Pörtner 2001). Without some degree of thermal tolerance or acclimation capacity that alleviates the energy demand of elevated temperature, poor ecological performance in the form of reduced rates of growth, reproductive dysfunction or even death will inevitably occur as ATP supply fails to meet demand at upper thermal limits (Pörtner \& Knust 2007). However, environmental stressors rarely occur in isolation, so other forms of environmental change are likely to interact and strain the metabolic performance of fish. Low $\mathrm{O}_{2}$ availability (hypoxia) presents a particular challenge because oxygen plays a key role in the electron transport chain and therefore indirectly influences the yield of ATP from oxidative phosphorylation. Exposure to warming waters and associated hypoxia, and the likelihood that this will intensify in marine ecosystems (Diaz \& Rosenberg 2008), poses a major threat to ATP supply-demand dynamics 
and will ultimately affect the ecological performance of many aquatic organisms.

Understanding the physiological and behavioural response of fish to rising temperature and low $\mathrm{O}_{2}$ (amongst other stressors such as ocean acidification) is thus very important to predict and manage fish populations as they respond to future environmental change (Jørgensen et al. 2012).

Whilst environmental stressors such as temperature and low $\mathrm{O}_{2}$ impose physiological limitations, fish are often mobile and do have the choice of moving away from deleterious conditions. The behavioural avoidance and preference reactions of fish may therefore be just as important as physiology in allowing fish to survive and cope with environmental challenge (Herbert et al. 2011). In the event that escape is futile, fish can employ other behavioural strategies (such as a reduction in swimming activity) to delay the manifestation of stress under environmentally adverse conditions (Herbert \& Wells 2001; Herbert \& Steffensen 2005; Domenici et al. 2013). Whilst physiology and behaviour have historically been considered in isolation, the Leigh Laboratory has and continues to provide a physical address for research that meld these traditionally separate fields with a simultaneous assessment of physiological and behavioural responses to environmental change.

\section{The metabolism and behaviour of fish in low $\mathrm{O}_{2}$}

Measures of physiological low $\mathrm{O}_{2}$ tolerance and behavioural avoidance have been developed at the Leigh Laboratory to provide a wider assessment of fish low $\mathrm{O}_{2}$ response. The value of integrating physiology and behaviour in low $\mathrm{O}_{2}$ challenge tests was originally highlighted by Herbert et al. (2011) who examined the low $\mathrm{O}_{2}$ avoidance behaviour of juvenile Atlantic cod, Gadus morhua, in different streams of oxygenated seawater. Avoidance behaviour was then compared against the known physiological threshold limit of the species (i.e. $P_{\text {crit }}$ which reflects the critical $\mathrm{O}_{2}$ level where fish can no longer regulate $\mathrm{O}_{2}$ uptake). Surprisingly, cod 
allowed to swim in water that was either $100 \% \mathrm{O}_{2}$ saturated or reduced to a critical $(20 \%$ level) of saturation did not avoid the dangerously low $\mathrm{O}_{2}$ level. However, in a secondary follow-up test, cod given an initial low $\mathrm{O}_{2}$ stress challenge avoided the critical $20 \%$ level of $\mathrm{O}_{2}$ saturation very strongly, suggesting that internal systemic stress rather than the absolute level of external low $\mathrm{O}_{2}$ triggers avoidance behaviour. Therefore, to further investigate the physiological basis of hypoxia avoidance behaviour in New Zealand fish, it was questioned whether the snapper (Pagrus auratus) would behaviourally avoid low $\mathrm{O}_{2}$ before or after physiological low $\mathrm{O}_{2}$ thresholds had been surpassed (in terms of $P_{\text {crit }}$ and stress) and whether long-term low $\mathrm{O}_{2}$ acclimation would improve their low $\mathrm{O}_{2}$ performance. To address these questions, the $P_{\text {crit }}$ limit of $P$. auratus was identified according to the sudden drop in standard metabolic rate (i.e. SMR or minimum maintenance rate)(Schurmann \& Steffensen 1997; Cook et al. 2011; Cook \& Herbert 2012b) and the avoidance behaviour of P. auratus in different streams of $\mathrm{O}_{2}$-manipulated seawater was assessed using a large choice tank equipped with behavioural tracking software (Fig. 3) (Cook et al. 2011, 2013; Cook \& Herbert 2012a; 2012b).

Whilst fish would be expected to avoid stress by leaving low $\mathrm{O}_{2}$ areas quickly, Leigh Laboratory experiments reveal that $P$. auratus only avoids low $\mathrm{O}_{2}$ at levels well below its physiological $P_{\text {crit }}$ limit and always in a state of major physiological stress (see Fig. 4) (Cook et al. 2011; Cook \& Herbert 2012a). P. auratus therefore appears to adopt a relatively high risk low $\mathrm{O}_{2}$ strategy and would probably not fare well if low $\mathrm{O}_{2}$ ever became frequent or widespread in coastal marine environments. Moreover, by reducing the $\mathrm{O}_{2}$ carrying capacity (i.e. anaemia state) of $P$. auratus with phenylhydrazine, two additional insights have been made (Cook et al. 2011): 1) Anaemic fish reach their $P_{\text {crit }}$ limit at higher $\mathrm{O}_{2}$ levels and also initiate avoidance at an earlier stage, indicating that additional stressors would probably sensitise the overall low $\mathrm{O}_{2}$ reaction of P. auratus (see Fig. 4). 2) Anaemic and 
normocythaemic fish avoid hypoxia at different levels but, interestingly, they leave low $\mathrm{O}_{2}$ with similar levels of physiological perturbation suggesting that "stress", rather than the absolute level of low $\mathrm{O}_{2}$, serves to trigger their avoidance reaction (Cook et al. 2011). From these experiments, it is concluded that $P$. auratus does not avoid low $\mathrm{O}_{2}$ safely and will probably struggle to survive extensive areas of hypoxia, especially if those areas are primed with additional stressors that reduce $\mathrm{O}_{2}$ carrying capacity (e.g. heavy metal exposure etc) (Cook et al. 2011; Cook and Herbert 2012a, 2012b).

Recognising that environmental change is not always a rapid process, the ability of $P$. auratus to improve its low $\mathrm{O}_{2}$ response after long-term hypoxia acclimation has also been addressed (Cook et al. 2013). Hypoxia-acclimated snapper were seen to select lower levels of $\mathrm{O}_{2}$ but did not show greater levels of blood and muscle disturbance (i.e. stress), showing that long-term hypoxia can improve the low $\mathrm{O}_{2}$ tolerance of $P$. auratus. However, based on the response of other fish in the literature, improved tolerance is not necessarily unexpected (Richards 2009) but the mechanism by which tolerance is achieved in snapper does appear unique. Whilst most fish generally show improved $\mathrm{O}_{2}$ extraction capacity (i.e. high haemoglobin- $\mathrm{O}_{2}$ binding affinity and blood $\mathrm{O}_{2}$ carrying capacity. Wood \& Johansen 1972; Wells 2009) snapper do not conform to the standard paradigm of low $\mathrm{O}_{2}$ adaptation because they show a surprising drop in $\mathrm{Hb}-\mathrm{O}_{2}$ affinity and $\mathrm{O}_{2}$ carrying capacity. This shift does not however compromise the $\mathrm{O}_{2}$ consumption rate of snapper so long-term hypoxia possibly conveys improved low $\mathrm{O}_{2}$ tolerance to snapper through a prioritisation of $\mathrm{O}_{2}$ delivery and/or utilisation over $\mathrm{O}_{2}$ uptake (Cook et al. 2013).Therefore, if we are to equip environmental management plans with a complete understanding of functional responses, more research will definitely be required to resolve the low $\mathrm{O}_{2}$ response of other non-exceptional coastal species because we clearly cannot rely on what is considered a "normal" response from the literature.

\section{The metabolic and behavioural response of fish in a warming world}


Climate change in the form of rising temperature affects individual organisms as well as the size, structure and distribution of their populations. Major biogeographical shifts have been observed in recent years (Perry et al. 2005; Dulvy et al. 2008) but the cause and effect of such change remains poorly understood. For example, a poleward shift in North sea fishes appears to occur at sub-critical temperatures (Perry et al. 2005) but it is still not known whether biogeographical shifts occur as a result of behavioural redistributions (behavioural thermoregulation), localized extinctions or community-level interactions. It is therefore relevant to ask whether New Zealand fish will actively seek out thermal environments that optimize their aerobic physiology and organismic performance or whether they will simply choose to stay and make the best of sub-optimal temperatures?

To address the likely response of fish to warming waters a common coastal fish was allowed to select its preferred temperature $\left(\mathrm{T}_{\text {pref }}\right)$ according to its choice of movement in a behavioural shuttle tank at the Leigh Laboratory. Behavioural $\mathrm{T}_{\text {pref }}$ was then compared against the temperature at which its aerobic metabolic scope (AMS) was maximised (Khan \& Herbert 2012). Interestingly, the common triplefin (Forsterygion lapillum) revealed a preferred behavioural temperature $\left(\mathrm{T}_{\text {pref }}\right)$ of $20-21{ }^{\circ} \mathrm{C}$ which sits within the range of temperatures where aerobic metabolic scope (AMS) was optimised $\left(15-21^{\circ} \mathrm{C}\right)$, suggesting that $F$. lapillum can track its thermal optimum. However, since this territorial species has such a wide range of AMS optimisation and appears to prefer high water temperatures, $F$. lapillum would probably not abandon a territory to move polewards or deeper to find more optimal temperatures conditions, at least for the foreseeable future. Furthermore, because the broad level of AMS optimisation implies that F. lapillum is highly eurythermic, more work is required to resolve the response of different ecotypes before generalisations can be drawn on the likely response of New Zealand fishes to warming waters. Further experiments are 
therefore underway to resolve the AMS and preference response of more mobile stenothermic species, such as the wreckfish groper (Polyprion oxygeneios) and snapper (P. auratus).

\section{Implications of metabolism and behaviour research for finfish aquaculture}

Understanding the physiology and behaviour of coastal marine fishes has potential spin off benefits for aquaculture as it also allows an optimisation of production processes. For example, aerobic metabolic scope (AMS) sets a limit to ecological performance by limiting the energy available for processes such as growth, reproduction and swimming activity (Claireaux \& Lefrançois 2005; Chabot \& Claireaux 2008); it therefore also serves as a good indicator of culture performance, as optimal growth is a basic ingredient for sustainable aquaculture (Frisk et al. 2012). There are two examples that illustrate how the metabolic scope framework was first applied to eco-physiology research at the Leigh Laboratory but then introduced successfully to aquaculture. The first example concerns the phenomenon of exercise-induced growth where fish show accelerated rates of growth as a result of sustained exercise at optimal swimming speeds (Herbert 2013; Davison \& Herbert 2013). Exercise and growth obviously compete for energetic resources but enhanced rates of growth are permitted at elevated swimming speeds if environmental conditions are sufficient to support a satisfactory level of aerobic metabolic scope (Davison \& Herbert 2013). This point was demonstrated by Brown et al. (2011) who identified that exercise could boost the growth and feed conversion efficiency of cultured kingfish (Seriola lalandi) but only at temperatures that do not constrain aerobic metabolic scope. The second example concerns the application of respirometry and thermal shuttle box techniques to resolve the response of coastal marine fish to climate change (i.e. global warming. Khan \& Herbert 2011). This research has proved useful because physiology and behaviour tests are now underway to establish the best 
temperature for optimal rearing by identifying the behavioural $\mathrm{T}_{\text {pref }}$ and AMS thermal optima of the wreckfish groper, Polyprion oxygeneios - a novel high value species for aquaculture in New Zealand. As aquaculture production processes are under continual pressure to improve the productivity, quality and welfare of their stock, an improved understanding of fish physiology and behaviour is becoming an increasingly vital area of aquaculture research.

\section{Questions arising from the Leigh laboratory contribution to ecophysiology}

Tracks of study developed through cycles of research conducted over 40 years raise a number of interesting questions with respect to all studies of near-shore marine systems and the animals living in them. A fundamental one might be around the capacity of the environment to impose stress on free-living animals. If as the above discussion suggests, physiological stress is a rare event, we might only expect detectable or sustained stress responses in wild fish in response to sustained environmental challenge or change. This effect is present in other vertebrates, particularly birds where unpredictable environmental changes such as extreme weather or storms initiate stress-mediated changes in behaviour (reviewed in Wingfield, 1994; Wingfield and Ramenofsky, 1999; Cyr and Romero, 2009). Interestingly extreme but predictable events do not have the same effect. Our capacity to test for effects of this type will become increasingly important in the face of predicted global climate shifts and our need to know what the impacts of these changes will be at the population and individual level.

Similarly, the demonstration of the importance of behaviour in modulating (and being modulated by) physiological processes is an element that is essentially missing from the majority of laboratory studies, but necessary for real understanding of biological processes. In all of these, the developmental research conducted at the Leigh Laboratory around a theme of ecophysiology has made a significant contribution to our understanding of how we should 
view the marine world from a physiological perspective. Future research should therefore harness what we have learned to date and take steps to refine and exploit the technological advances of recent years. For example, with the recent revolution of telemetry techniques, the laboratory is not the only setting in which physiological and behavioural investigations can be made. Indeed, traditional acoustic tracking techniques (e.g. Hartill et al. 2003) could theoretically be coupled with new bio-logging technology to provide insight to the physiology and energetics of free swimming fishes (e.g. Clark et al. 2010) as they engage in reproduction and/or selectively move between environmental gradients (e.g. oxygen, Svendsen et al. 2006) in the wild.

With respect to climate change there is accumulating evidence that global warming is a real threat (IPCC 2007) so all marine and terrestrial species will face a slow but significant rise in temperature with an associated shift in ecosystem function as flora and fauna meet their upper thermal limits. New Zealand is not exempt from the forecast rise in temperature but, whilst climate change research is not yet a priority research area for this country, we still have a lot to learn about how our unique fauna will respond. It is already clear that rising temperatures will have significant consequences for fish reproduction and recruitment (Pankhurst \& Munday 2011) but other forms of stress, such as low $\mathrm{O}_{2}$, are set to exacerbate the problem through constrained metabolism (Claireaux and Lefrançois 2005; Chabot \& Claireaux 2008). Aquatic hypoxia has increased globally and expanded in many areas in recent years (Diaz \& Rosenberg 2008) but low $\mathrm{O}_{2}$ episodes still appear to be relatively isolated in New Zealand (Larkin 2005; Patel 2011). However, with proposed shifts in land use and a continuance of human pressure, relatively enclosed water bodies such as estuaries, harbours and even the Firth of Thames (which sits at the southern end of the Hauraki Gulf and receives nutrients from the Waikato farming region), are probably not immune to the future threat of severe low $\mathrm{O}_{2}$ through eutrophication (Larkin 2005; Hauraki Gulf Forum 
2008, 2011; Patel 2011). In light of the possible combined threat of elevated temperature and low $\mathrm{O}_{2}$, a precautionary approach would be to resolve the response of keystone species, such as the snapper $P$. auratus, in advance of any environmental change, and to have management plans equipped with a full understanding of the responses expected from as many species as possible (Jørgensen et al. 2012). This is an important new line of research for the Leigh Laboratory, because studies examining the physiology and behaviour of fish to low $\mathrm{O}_{2}$ and elevated temperature will almost certainly provide vital information for the models that forecast the abundance and distribution of fish in a changing world (Jørgensen et al. 2012).

\section{References}

Ayling AM, Cumming A, Ballantine WJ 1981. Map of shore and subtidal habitats of the Cape Rodney-Okakari Point Marine Reserve, North Island, New Zealand, in 3 sheets, scale 1:2000. Department of Lands and Survey, Wellington.

Babcock RC, Kelly S, Shears NT, Walker JW, Willis TJ 1999. Changes in community structure in temperate marine reserves. Marine Ecology Progress Series 189: 125134.

Barnett CW, Pankhurst NW 1994. Changes in plasma levels of gonadal steroids and gonad morphology during the spawning cycle of male and female demoiselles Chromis dispilus (Pisces: Pomacentridae). General and Comparative Endocrinology 93: 260274.

Barnett CW, Pankhurst NW 1996. Effect of population density on the reproductive behaviour of the territorial male demoiselle Chromis dispilus (Pisces: Pomacentridae). Environmental Biology of Fishes 46: 343-349. 
Barton BA 2002. Stress in fishes: A diversity of responses with particular reference to changes in circulating corticosteroids. Integrative and Comparative Biology 42: 517525.

Barton BA, Iwama GK 1991. Physiological changes in fish from stress in aquaculture with emphasis on the response and effects of corticosteroids. Annual Review of Fish Diseases 1: 3-26.

Bollard BA, Pankhurst NW, Wells RMG 1993. Effects of artificially elevated plasma cortisol levels on blood parameters in the teleost fish Pagrus auratus (Sparidae). Comparative Biochemistry and Physiology 106A: 157-162.

Brix O, Clements KD, Wells RMG 1998. An ecophysiological interpretation of hemoglobin multiplicity in three herbivorous marine teleost species from New Zealand. Comparative Biochemistry and Physiology 121A: 189-195.

Brix O, Clements KD, Wells RMG 1999. Haemoglobin components and oxygen transport in relation to habitat distribution in triplefin fishes [Tripterygiidae]. Journal of Comparative Physiology B 169: 329-334.

Brown EJ, Bruce M, Pether S, Herbert NA 2011. Do swimming fish always grow fast? Investigating the magnitude and physiological basis of exercise-induced growth in juvenile New Zealand yellowtail kingfish, Seriola lalandi. Fish Physiology and Biochemistry 37: 327-336.

Cardwell JR, NR Liley 1991. Androgen control of social status in males of a wild population of stoplight parrotfish, Sparisoma viride (Scaridae). Hormones and Behavior 25: 1-18. Carragher JF, Pankhurst NW 1991. Stress and reproduction in a commercially important marine fish, Pagrus auratus (Sparidae). In: Scott AP, Sumpter JP, Kime DE, Rolfe MS eds. Reproductive Physiology of Fish 1991. FishSymp 91, Sheffield. Pp. 253255. 
Carragher JF, Pankhurst NW 1993. Plasma levels of sex steroids during sexual maturation of snapper Pagrus auratus (Sparidae), caught from the wild. Aquaculture 109: 375388.

Chabot D, Claireaux G 2008. Environmental hypoxia as a metabolic constraint on fish: The case of Atlantic cod, Gadus morhua. Marine Pollution Bulletin 57: 287-294.

Claireaux G, Lefrançois C 2005. Ecological implications of environmental influences on the aerobic metabolic scope of fish. Comparative Biochemistry and Physiology 141A: S165.

Clark TD, Sandblom E, Hinch SG, Patterson DA, Frappell PB, Farrell AP 2010. Simultaneous biologging of heart rate and acceleration, and their relationships with energy expenditure in free-swimming sockeye salmon (Oncorhynchus nerka). Journal of Comparative Physiology B 180: 673-684.

Cleary JJ, Battaglene SC, Pankhurst NW 2002. Capture and handling stress affects the endocrine and ovulatory response to exogenous hormone treatment in snapper, Pagrus auratus (Bloch \& Schneider). Aquaculture Research 33: 1-10.

Clearwater JC, Pankhurst NW 1994. Reproductive biology and endocrinology of female red gurnard Chelidonichthys kumu (Lesson and Garnot) (Family Triglidae), from the Hauraki Gulf, New Zealand. Australian Journal of Marine and Freshwater Research 45: 131-139.

Clearwater JC, Pankhurst NW 1997. The response to capture and confinement stress of plasma cortisol, plasma sex steroids and vitellogenic oocytes in the marine teleost, red gurnard (Chelidonichthys kumu) (Triglidae). Journal of Fish Biology 50: 429441.

Cockrem JF In press. Individual variation in glucocorticoid stress responses in animals. General and Comparative Endocrinology. 
Cole RG 1994. Abundance, size structure and diver-oriented behaviour of three large benthic carnivorous fishes in a marine reserve in northeastern New Zealand. Biological Conservation 70:93-99.

Cook DG, Herbert NA 2012a. Low $\mathrm{O}_{2}$ avoidance is associated with physiological pertubation but not exhaustion in the snapper (Pagrus auratus: Sparidae). Comparative Biochemistry and Physiology 162A: 310-316.

Cook DG, Herbert NA 2012b. The physiological and behavioural response of juvenile kingfish (Seriola lalandi) differs between escapable and inescapble progressive hypoxia. Journal of Experimental Marine Biology and Ecology 413: 138-144.

Cook DG, Iftikar FI, Baker DW, Hickey AJR, Herbert NA 2013. Low $\mathrm{O}_{2}$ acclimation shifts the hypoxia avoidance behaviour of snapper (Pagrus auratus) with only subtle changes in aerobic and anaerobic function. Journal of Experimental Biology 216: 369 378.

Cook DG, Wells RMG, Herbert NA 2011. Anaemia adjusts the aerobic physiology of snapper (Pagrus auratus) and modulates hypoxia avoidance behaviour during oxygen choice presentations. Journal of Experimental Biology 214: 2927-2934.

Cucco A, Sinerchia M, Lefrançois C, Magni P, Ghezzo M, Umgiesser G, Perilli A, Domenici P 2012. A metabolic scope based model of fish response to environmental changes. Ecological Modelling 237: 132-141.

Cyr NE, Romero LM 2009. Identifying hormonal habituation in field studies of stress. General and Comparative Endocrinology 161: 295-303.

Davison W, Herbert NA 2013. Swimming-enhanced growth. In: Palstra AP, Planas JV eds. Swimming physiology of fish. Towards using exercise for farming a fit fish in sustainable aquaculture. Springer, Berlin. Pp. 177-202. 
Dedual M, Pankhurst NW 1992. Plasma steroid hormone concentrations in relation to the reproductive cycle of the sweep Scorpis lineolatus (Kyphosidae) caught from the wild. Australian Journal of Marine and Freshwater Research 43: 753-763.

Diaz RJ, Rosenberg R 2008. Spreading dead zones and consequences for marine ecosystems. Science 321: 926-929.

Domenici P, Herbert NA, Lefrançois C, Steffensen JF, McKenzie DJ 2013. The effect of hypoxia on fish swimming performance and behaviour. In: Palstra AP, Planas JV eds. Swimming physiology of fish. Towards using exercise to farm a fit fish in sustainable aquaculture. Springer, Berlin. Pp. 129-159.

Dulvy NK, Rogers SI, Jennings S, Stelzenmüller V, Dye SR, Skjoldal HR 2008. Climate change and deepening of the North Sea fish assemblage: a biotic indicator of warming seas. Journal of Applied Ecology 45: 1029-1039.

Eros SK, Milligan CL 1996. The effect of cortisol on recovery from exhaustive exercise in rainbow trout (Oncorhynchus mykiss): Potential mechanisms of action. Physiological Zoology 69: 1196-1214.

Frisk M, Skov PV, Steffensen JF 2012. Thermal optimum for pikeperch (Sander lucioperca) and the use of ventilation frequency as a predictor of metabolic rate. Aquaculture 324: $151-157$.

Grutter AS, Pankhurst NW 2000. The effects of capture, handling, confinement and ectoparasite load on plasma levels of cortisol, glucose, and lactate in the coral reef fish Hemigymnus melapterus (Labridae). Journal of Fish Biology 57: 391-401.

Haddy JA, Pankhurst NW 2000. The efficacy of exogenous hormones in stimulating changes in plasma steroids and ovulation in wild black bream Acanthopagrus butcheri is improved by treatment at capture. Aquaculture 191: 351-366. 
Hartill BW, Morrison MA, Smith MD, Boubee J, Parsons DM 2003. Diurnal and tidal movements of snapper (Pagrus auratus, Sparidae) in an estuarine environment. Marine and Freshwater Research 54: 931-940.

Hauraki Gulf Forum (2008) State of our Gulf. Tikapa Moana - State of the Environment Report 2008. Auckland Council. Pp. 1-100.

Hauraki Gulf Forum (2011) State of our Gulf. Tikapa Moana - State of the Environment Report 2008. Auckland Council. Pp. 1-164.

Herbert NA 2013. Practical aspects of induced exercise in finfish aquaculture. In: Palstra AP, Planas JV eds. Swimming physiology of fish. Towards using exercise for farming a fit fish in sustainable aquaculture. Springer, Berlin. Pp. 377-405.

Herbert NA, Steffensen JF 2005. The response of Atlantic cod, Gadus morhua, to progressive hypoxia: fish swimming speed and physiological stress. Marine Biology 147: 14031412.

Herbert NA, Wells RMG 2001. The aerobic physiology of the air-breathing blue gourami, Trichogaster trichopterus, necessitates behavioural regulation of breath-hold limits during hypoxic stress and predatory challenge. Journal of Comparative Physiology B 171: 603-612.

Herbert NA, Skjæraasen JE, Nilsen T, Salvanes AG, V, Steffensen JF 2011. The hypoxia avoidance behaviour of juvenile Atlantic cod (Gadus morhua L.) depends on the provision and pressure level of an $\mathrm{O}_{2}$ refuge. Marine Biology 158: 737-746.

Hickey AJR 2004. Evolution of New Zealand's triplefin fish (Family Tripterygiidae). Unpublished PhD thesis, The University of Auckland, Auckland, New Zealand.

Hickey AJR, Clements KD 2003. Key metabolic enzymes and muscle structure in triplefin fishes (Tripterygiidae): a phylogenetic comparison. Journal of Comparative Physiology B 173: 113-123. 
Hickey AJR, Clements KD 2005. Genome size evolution in New Zealand triplefin fishes. Journal of Heredity 96: 356-362.

Hilton Z 2010. Physiological adaptation in the radiation of New Zealand triplefin fishes (Family Tripterygiidae). Unpublished PhD thesis, The University of Auckland, Auckland, New Zealand.

Hilton Z, Clements KD, Hickey AJR 2010. Temperature sensitivity of cardiac mitochondria in intertidal and subtidal triplefin fishes. Journal of Comparative Physiology B 180: 979-990.

Hilton Z, Wellenreuther M, Clements KD 2008. Physiology underpins habitat partitioning in a sympatric sister-species pair of intertidal fishes. Functional Ecology 22: 1108-1117.

Hobby AC, Pankhurst NW 1997. The relationship between plasma and ovarian levels of gonadal steroids in the repeat spawning marine fishes Pagrus auratus (Sparidae) and Chromis dispilus (Pomacentridae). Fish Physiology and Biochemistry 16: 65-75.

IPCC 2007. In Climate change 2007: the physical science basis. Cambridge University Press, Cambridge.

Jørgensen C, Peck MA, Antognarelli F, Azzurro E, Burrows MT, Cheung WWL, Cucco A, Holt RE, Huebert KB, Marras S, McKenzie D, Metcalfe J, Perez-Ruzafa A, Sinerchia M, Steffensen JF, Teal LR, Domenici P 2012. Conservation physiology of marine fishes: advancing the predictive capacity of models. Biology Letters 8: 900-903.

Khan JR, Herbert NA 2012. The behavioural thermal preference of the common triplefin (Forsterygion lapillum) tracks aerobic scope optima at the upper thermal limit of its distribution. Journal of Thermal Biology 37: 118-124.

Kindler PM, Philipp DP, Gross MR, Bahr JM 1989. Serum 11-ketotestosterone and testosterone concentrations associated with reproduction in male bluegill (Lepomis machrochirus: Centrarchidae). General and Comparative Endocrinology 75: 446-453. 
Krebs CJ 1994. Ecology (Fourth Edition). Addison Wesley Educational Publishers, Mento Park, California. 801p.

Kroon FJ, Munday PL, Pankhurst NW 2003. Steroid hormone levels and bi-directional sex change in Gobiodon histrio. Journal of Fish Biology 62: 153-167.

Kroon FJ, Munday PL, Westcott DA 2009. Equivalent whole-body concentrations of 11ketotestosterone in female and male coral goby Gobiodon erythrospilus, a bidirectional sex-changing fish. Journal of Fish Biology 75: 685-692.

Larkin GJA 2005. Hypoxia in the Kaikorai Estuary: dynamics, causes and biological impacts. Unpublished Master of Science thesis, University of Otago, Dunedin, New Zealand.

Ling N, Wells RMG 1985a. Changes in blood metabolites following stress from capture and handling of the marine teleost Girella tricuspidata. Comparative Biochemistry and Physiology 82A: 609-612.

Ling N, Wells RMG 1985b. Plasma catecholamines and erythrocyte swelling following capture stress in a marine teleost fish. Comparative Biochemistry and Physiology 82C: $231-234$.

Lowe TE, Ryder JM, Carragher JF, Wells RMG 1993. Flesh quality in snapper, Pagrus auratus, affected by capture stress. Journal of Food Science 58: 770-\&.

Lowe TE, Wells RMG 1996. Primary and secondary stress responses to line capture in the blue mao mao. Journal of Fish Biology 49: 287-300.

Magee SE, Neff BD, Knapp R 2006. Plasma levels of androgen and cortisol in relation to breeding behaviour in parental male bluegill sunfish, Lepomis macrochirus. Hormones and Behavior 49: 598-609.

McCormick MI 1998. Behaviorally induced maternal stress in a fish influences progeny quality by a hormonal mechanism. Ecology 79: 1873-1883. 
McCormick MI 2006. Mothers matter: Crowding leads to stressed mothers and smaller offspring in marine fish. Ecology 87: 1104-1109.

Pankhurst NW 1990. Changes in plasma levels of gonadal steroids during spawning behaviour in territorial male demoiselles Chromis dispilus (Pisces: Pomacentridae) sampled underwater. General and Comparative Endocrinology 79: 215-225.

Pankhurst NW 1995. Hormones and reproductive behaviour in male damselfish. Bulletin of Marine Science 57: 569-581.

Pankhurst NW 1998. Reproduction. In: Black KD, Pickering AD eds. Biology of Farmed Fish. Sheffield Academic Press, Sheffield. Pp. 1-26.

Pankhurst NW 2001. Stress inhibition of reproductive endocrine processes in a natural population of the spiny damselfish Acanthochromis polyacanthus. Marine and Freshwater Research 52: 753-761.

Pankhurst NW 2011. The endocrinology of stress in fish: an environmental perspective. General and Comparative Endocrinology 170: 265-275.

Pankhurst NW, Barnett CW 1993. Relationship of population density, territorial interaction and plasma levels of gonadal steroids in spawning male demoiselles Chromis dispilus (Pisces: Pomacentridae). General and Comparative Endocrinology 90: 168176.

Pankhurst NW, Carragher JF 1995. Effect of exogenous hormones on reproductive behaviour in territorial males of a natural population of demoiselles Chromis dispilus (Pisces: Pomacentridae). Marine and Freshwater Research 46: 1201-1209.

Pankhurst NW, Dedual M 1994. Effects of capture and recovery on plasma levels of cortisol, lactate and gonadal steroids in a natural population of rainbow trout, Oncorhynchus mykiss. Journal of Fish Biology 45: 1013-1025. 
Pankhurst NW, Kime DE 1991. Plasma sex steroid concentrations in male blue cod, Parapercis colias (Bloch and Schneider) (Pinguipedidae), sampled underwater during the spawning season. Australian Journal of Marine and Freshwater Research 42: 129137.

Pankhurst NW, Munday PL 2011. Effects of climate change on fish reproduction and early life history stages. Marine and Freshwater Research 62: 1015-1026.

Pankhurst NW, Peter RE 2002. Changes in levels of gonadal steroids and putative gonadotropin in association with spawning and brooding behavior of male demoiselles. Journal of Fish Biology 61: 394-404.

Pankhurst NW, Sharples DF 1992. Effects of capture and confinement on plasma cortisol levels in the snapper Pagrus auratus. Australian Journal of Marine and Freshwater Research 43: 345-356.

Pankhurst NW, Van Der Kraak G 1997. Effects of stress on growth and reproduction. In: Iwama GK, Pickering AD, Sumpter JP, Schreck CB eds. Fish Stress and Health in Aquaculture, Cambridge University Press, Cambridge. Pp. 73-93.

Pankhurst NW, Fitzgibbon QP, Pankhurst PM, King HR, 2008a. Habitat-related variation in reproductive endocrine condition in the coral reef damselfish Acanthochromis polyacanthus. General and Comparative Endocrinology 155: 386-397.

Pankhurst NW, Fitzgibbon QP, Pankhurst PM, King HR 2008b. Density effects on reproduction in natural populations of the staghorn damsel, Amblyglyphidodon curacao. Cybium 32 (Suppl 2): 297-299.

Pankhurst NW, Hilder PI, Pankhurst PM 1999. Reproductive condition and behavior in relation to plasma levels of gonadal steroids in the spiny damselfish Acanthochromis polyacanthus. General and Comparative Endocrinology 115: 53-69. 
Pankhurst NW, Wells RMG, Carragher JF 1992. Effects of stress on plasma cortisol levels and blood viscosity in blue mao mao Scorpis violaceus (Hutton), a marine teleost. Comparative Biochemistry and Physiology 101A: 335-339.

Patel BN 2011. The response of juvenile snapper, Pagrus auratus, to enviornmental hypoxia and oxygen profiles in the Mahurangi estuary, Auckland region. Unpublished Master of Science thesis, The University of Auckland, Auckland, New Zealand.

Perry AL, Low PJ, Ellis JR, Reynolds JD 2005. Climate change and distribution shifts in marine fishes. Science 308: 1912-1915.

Pickering AD 1998. Stress responses of farmed fish. In: Black KD, Pickering AD eds. Biology of Farmed Fish. Sheffield Academic Press, Sheffield. Pp. 222-255.

Poortenaar CW, Hooker SH, Sharp N 2001. Assessment of yellowtail kingfish (Seriola lalandi lalandi) reproductive physiology as a basis for aquaculture development. Aquaculture 201: 271-286.

Poortenaar CW, Woods CMC, James PJ, Giambartolomei FM, Lokman PM 2004. Reproductive biology of female big-bellied seahorses. Journal of Fish Biology 64: 717-725.

Pörtner HO 2001. Climate change and temperature-dependent biogeography: oxygen limitation of thermal tolerance in animals. Naturwissenschaften 88: 137-146.

Pörtner HO, Knust R 2007. Climate change affects marine fishes through the oxygen limitation of thermal tolerance. Science 315: 95-97.

Rankin JC, Jensen FB 1993. Fish ecophysiology: the comparative physiologist's viewpoint. In: Rankin JC, Jensen FB eds. Fish Ecophysiology. Chapman and Hall, London. Pp. $17-20$

Richards JG 2009. Metabolic and molecular responses of fish to hypoxia. In: Richards JG, Farrell AP, Brauner CJ eds. Hypoxia. Elsevier, London. Pp. 443-485. 
Ryan SN, Pankhurst NW, Wells RMG 1995. A possible role for ubiquitin in the stress response of the teleost fish blue mao mao (Scorpis violaceus). Physiological Zoology 68: 1077-1092.

Schreck CB 2010. Stress and fish reproduction: The roles of allostasis and hormesis. General and Comparative Endocrinology 165: 549-556.

Schurmann H, Steffensen JF 1997. Effects of temperature, hypoxia and activity on the metabolism of juvenile Atlantic cod. Journal of Fish Biology 50: 1166-1180.

Scott NE, Mackenzie DS, Stacey NE 1984. Endocrine changes during natural spawning in the white sucker, Catostomus commersoni. II. Steroid hormones. General and Comparative Endocrinology 56: 349-359.

Sikkel PC 1993. Changes in plasma androgen levels associated with changes in male reproductive behavior in a brood cycling marine fish. General and Comparative Endocrinology 89: 229-237.

Stacey NE 1984. Control of the timing of ovulation by exogenous and endogenous factors. In: Potts GW, Wootton RJ eds. Fish Reproduction: Strategies and Tactics. Academic Press, London. Pp. 207-222.

Stacey NE, Mackenzie DS, Marchant TA, Kyle AL, Peter RE 1984. Endocrine changes during natural spawning in the white sucker Catostomus commersoni. I. Gonadotropin, growth hormone, and thyroid hormones. General and Comparative Endocrinology 56: 333-348.

Sumpter JP 1997. The endocrinology of stress. In: Iwama GK, Pickering AD, Sumpter JP, Schreck CB eds. Fish Stress and Health in Aquaculture. Cambridge University Press, Cambridge. Pp. 95-118. 
Svendsen JC, Aarestrup K, Steffensen JF, Herskin J 2006. Use of a novel acoustic dissolved oxygen transmitter for fish telemetry. Marine Technology Society Journal 40: 103 108.

Teal LR, van Hal R, van Kooten T, Ruardij P, Rijnsdorp AD 2012. Bio-energetics underpins the spatial response of North Sea plaice (Pleuronectes platessa L.) and sole (Solea solea L.) to climate change. Global Change Biology 18: 3291-3305.

Wells RMG 1987. Stress responses imposed by fish capture and handling - A physiological perspective. Food Technology in Australia 39: 479-481.

Wells RMG 2009. Blood-gas transport and hemoglobin function: Adaptations for functional and enviornmental hypoxia. In: Richards JG, Farrell AP, Brauner CJ eds. Hypoxia. Academic Press, London. Pp. 256-301.

Wells RMG, McNeil H, Macdonald JA 2005. Fish hypnosis: Induction of an atonic immobility reflex. Marine and Freshwater Behaviour and Physiology 38: 71-78.

Wendelaar Bonga SE 1997. The stress response in fish. Physiological Reviews 77: 591-625. Wingfield JC 1994. Modulation of the adrenocortical response to stress in birds. In: Davey KG, Peter RE, Tobe SS eds. Perspectives in Comparative Endocrinology, National Research Council of Canada, Ottawa. Pp. 520-528.

Wingfield JC, Ramenofsky M 1999. Hormones and the behavioural ecology of stress. In: Balm PHM ed. Stress Physiology in Animals. Sheffield Academic Press, Sheffield. Pp. 1-51.

Withers PC 1992. Comparative Animal Physiology. Saunders College Publishing, Fort Worth. 949p.

Wood SC, Johansen K 1972. Adaptation to hypoxia by increased $\mathrm{Hb}_{-} \mathrm{O}_{2}$ Affinity and decreased red cell ATP concentration. Nature New Biology 237: 278-281. 


\section{Figure Legends}

Fig. 1 The development of simple tools for managing underwater blood sampling (A), and the capacity to capture and sample diver positive fish in the Leigh Reserve (B) allowed realtime association between behaviour, and plasma hormone levels.

Fig. 2 A model summarising the interaction of social factors, behaviour and endocrine condition in territorial male demoiselles Chromis dispilus. T - testosterone, $11 \mathrm{KT}-11$ -

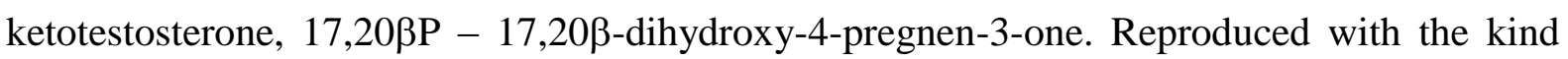
permission of Allen Press from Pankhurst 1995.

Fig. 3 Diagrammatic representation of the low $\mathrm{O}_{2}$ choice test tank used by Cook et al. at the Leigh laboratory. Water passing through gassing towers (GT) was either aerated or deoxygenated (with nitrogen gas) before passing through the inflow into the choice box. Oxygen sensors $\left(\mathrm{DO}_{\mathrm{S}}\right)$ enabled control of inflow $\mathrm{O}_{2}$. Water was passed initially through coarse diffusers before flowing through two fine honeycomb baffles $(\mathrm{HcB})$ creating strictly laminar flow within the behavioural arena (BA). Water would drain to sumps before being pumped $(\mathrm{P})$ back to the gassing towers. A video camera $(\mathrm{V})$ enabled observation and SwisTrack behavioural tracking software was used to record fish movement and choice within the experimental apparatus. See Cook et al. (2012b) for more detail. Image reproduced with permission from Elsevier.

Fig. 4 The physiological (metabolic) and behavioural avoidance response of a) normocythaemic and B) anaemic snapper ( $P$. auratus $)$ at $18^{\circ} \mathrm{C}$. Heavy dashed lines represent the SMR extrapolated across the relevant range of $\mathrm{O}_{2}$ availability denoted in terms of $\mathrm{O}_{2}$ partial pressure $\left(\mathrm{PO}_{2}\right.$ in kilopascals), with light dashed lines representing the $95 \%$ confidence intervals. Circular symbols indicate points of MMR $\pm 95 \% \mathrm{CI}$ at the measured level of $\mathrm{PO}_{2}$. The vertical solid red line represents the behavioural avoidance $P_{2}$ of the treatment with 
dashed red lines representing the $95 \%$ CI. Symbols denoted with an * indicate significant differences from the corresponding normocythaemic value. See Cook et al. (2011) for extra detail. Reproduced with kind permission from the Company of Experimental Biologists. 

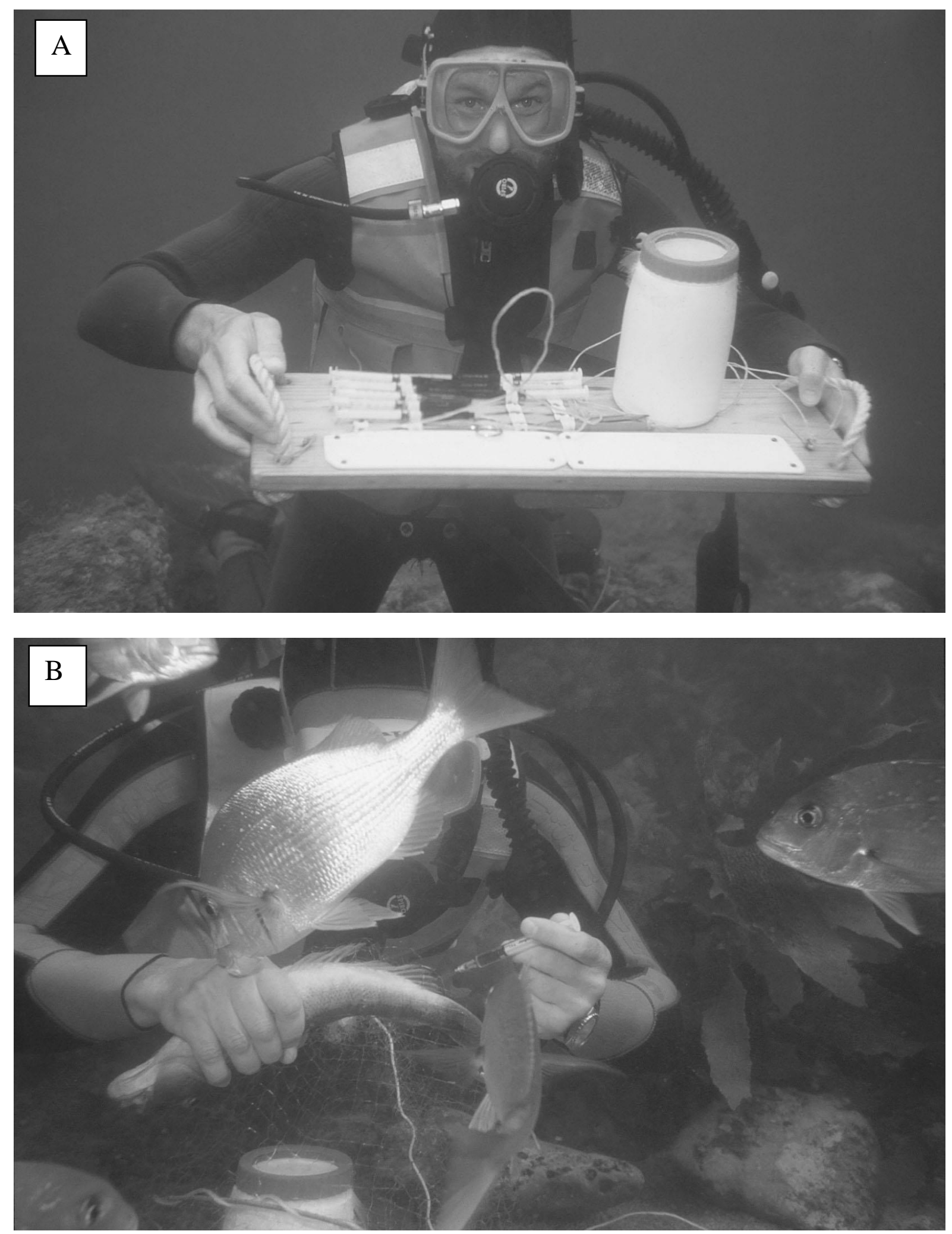

Fig. 1 


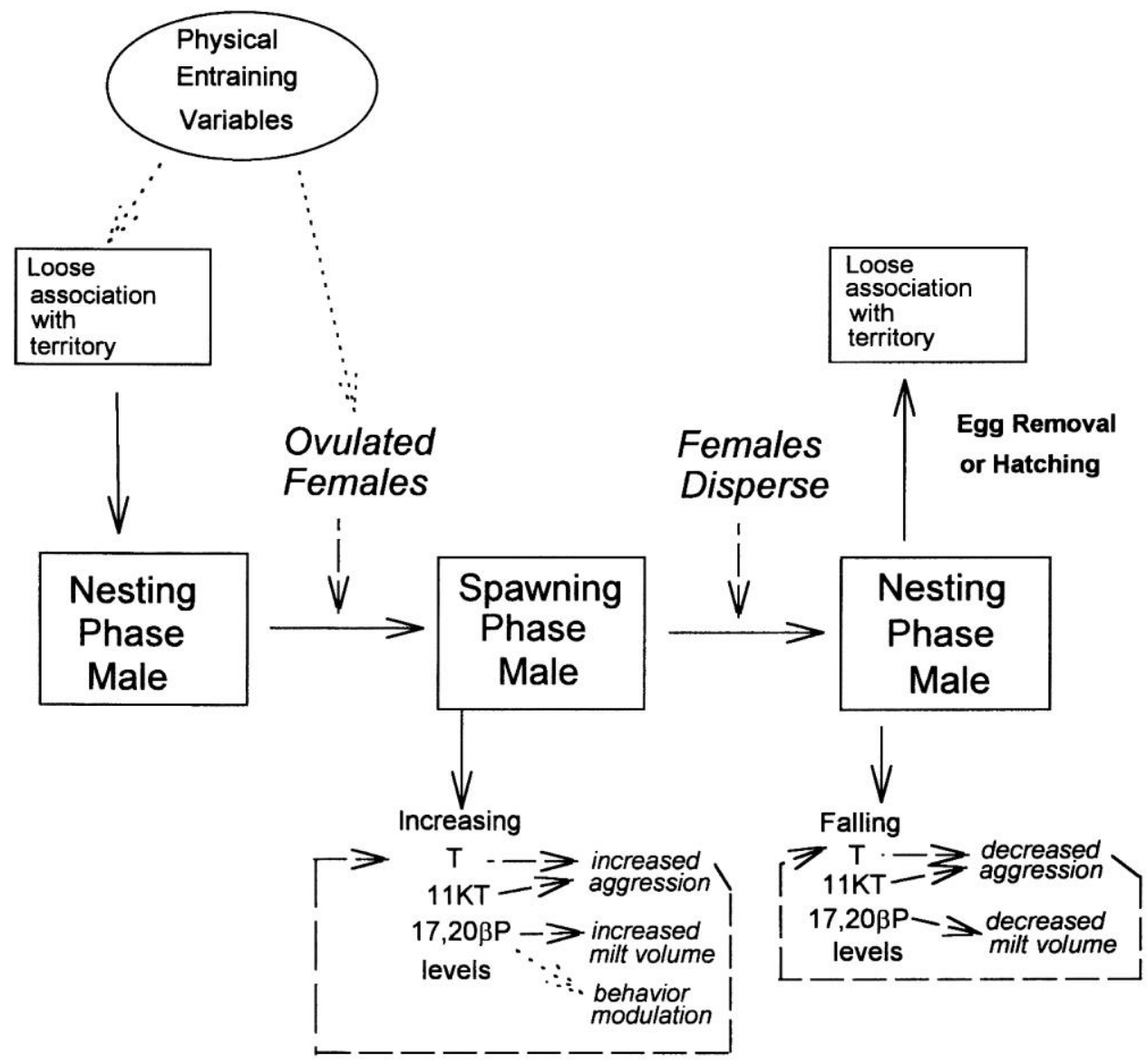

Fig. 2 
Fig. 3

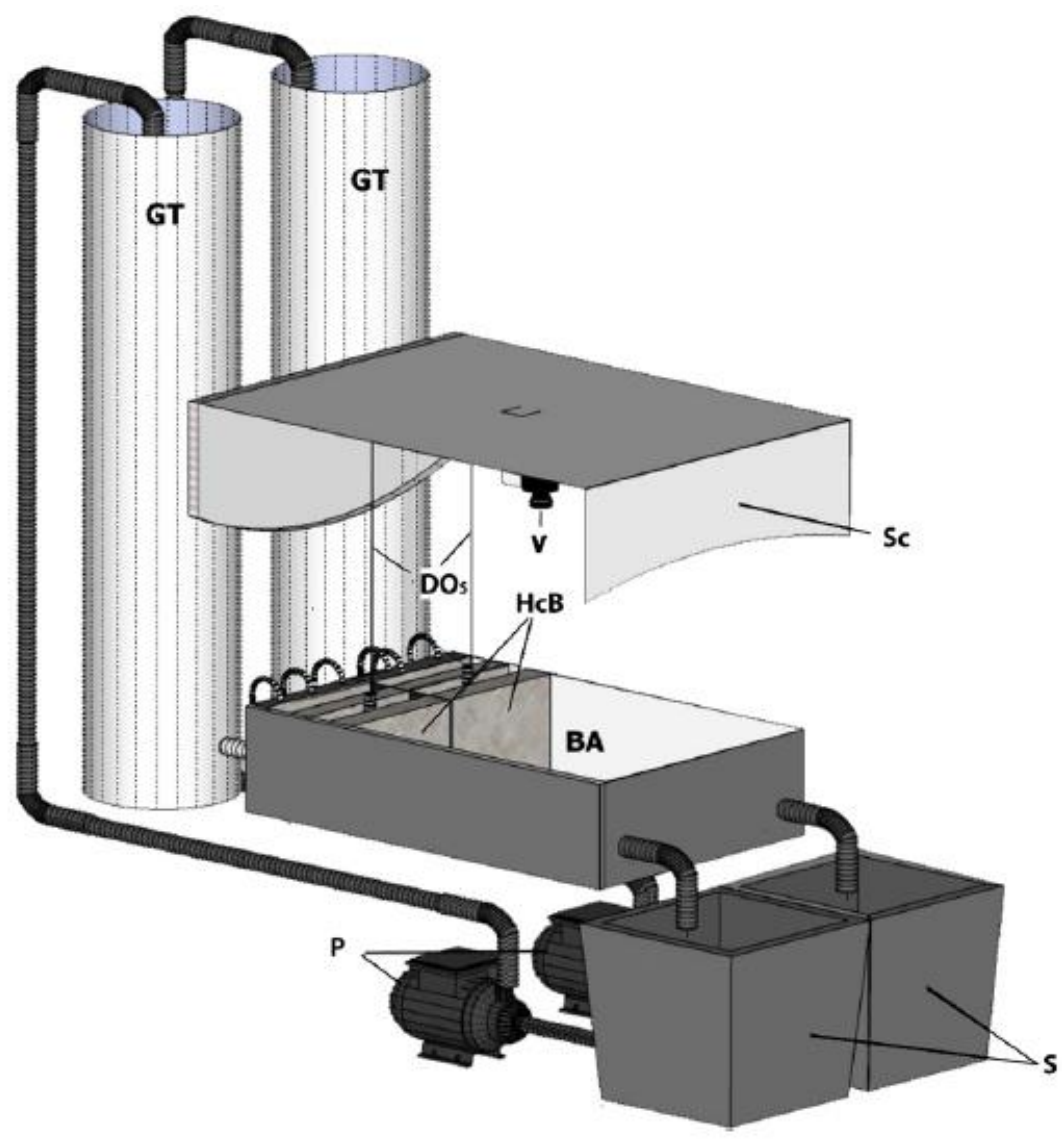


Fig. 4

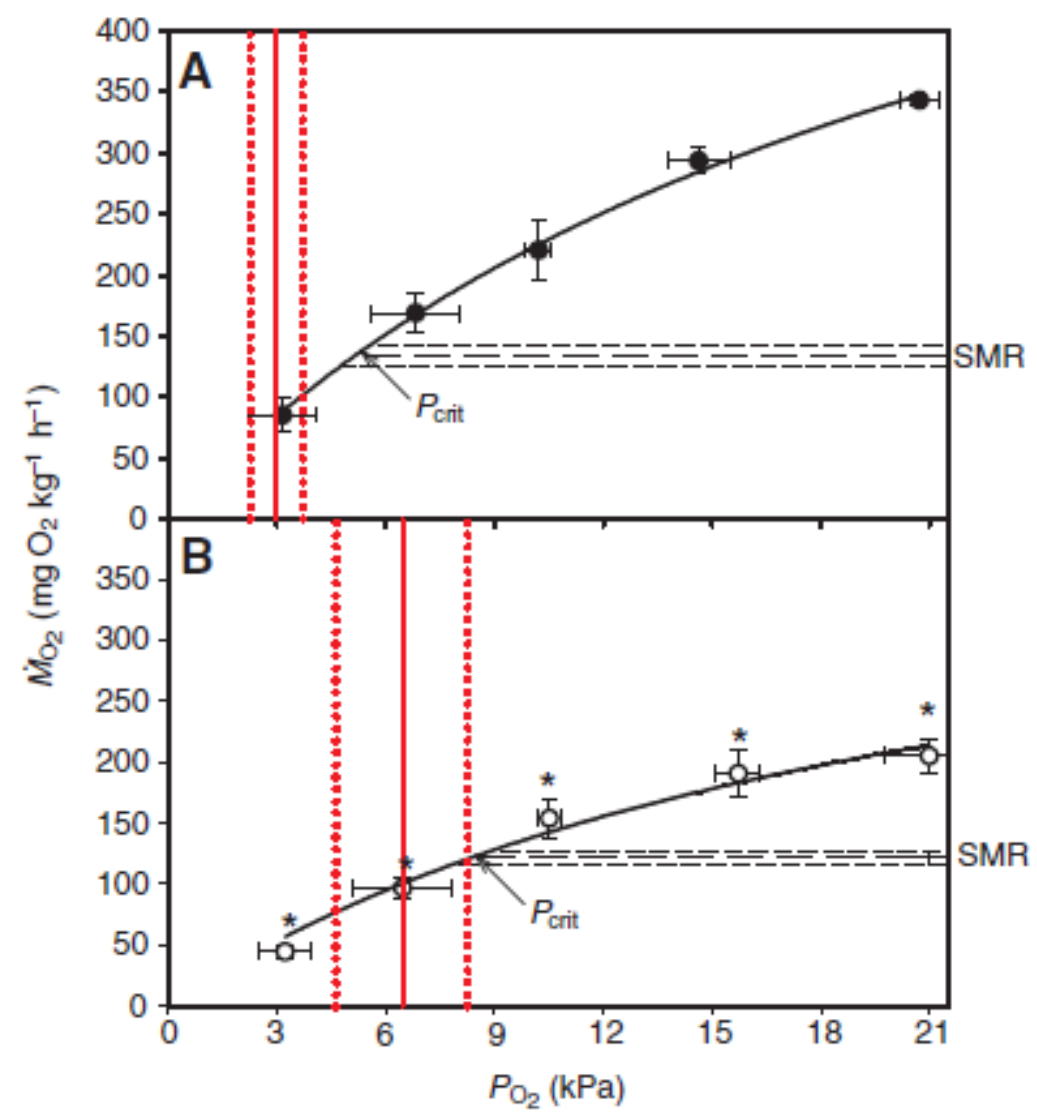

